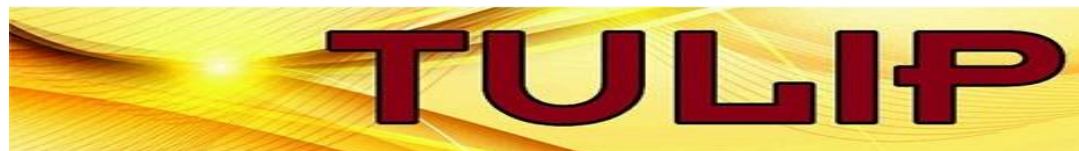

TULISAN ILMIAH PARIWISATA

\title{
PERAN MASYARAKAT LOKAL DALAM PENGELOLAAN DAYA TARIK WISATA ALAM ARUNG JERAM PAPUALANGI KABUPATEN GORONTALO UTARA
}

\author{
Desrika Talib \\ desrikatalib@gmail.com \\ Dosen Pariwisata, FIB_UMGo, Jl.Prof Mansoer Pateda, Indonesia \\ Nur Fadliyah Usu \\ nurfadliyahusu@gmail.com, \\ Wahawiswa, Pariwisata, FIB_UMGo, JI.Prof Mansoer Pateda, Indonesia
}

\begin{abstract}
Abstrak
Saat ini kegiatan pariwisata di Indonesia mengalami perkembangan yang pesat, hal ini dapat dilihat dari berbagai macam daerah-daerah yang ada di Indonesia dalam mengembangkan destinasi-destinasi wisata yang ada di daerahnya masing-masing. Dalam Undang-undang Nomor 10 Tahun 2009 yang menyebutkan bahwa keberadaan daya tarik wisata pada suatu daerah akan sangat menguntungkan, diantaranya untuk meningkatkan taraf hidup masyarakat, memperluas kesempatan kerja, meningkatkan Pendapatan Asli Daerah (PAD), kemudian meningkatkan rasa cinta lingkungan serta melestarikan alam dan budaya setempat. Keberadaan sektor pariwisata dalam suatu wilayah dapat memberikan dampak positif maupun negative. Namun, pada dasarnya tergantung pada manajemen dan tata pengelolaan kepariwisataan yang diperankan oleh segenap pemangku kepentingan baik dari unsur pemerintah, swasta maupun masyarakat yang ada pada wilayah tersebut. Pencapaian tujuan dan misi pembangunan kepariwisataan yang baik, berkelanjutan (sustainable tourism) dan berwawasan lingkungan akan dapat terlaksana manakala dalam proses pencapaiannya dapat dilakukan melalui tata kelola kepariwisataan yang baik. (good tourism governance). Prinsip dari penyelenggaraan tata kelola kepariwisataan yang baik adalah adanya koordinasi dan sinkronisasi program antar pemangku kepentingan yang ada serta dilibatkannya partisipasi aktif yang sinergis (terpadu dan saling menguatkan) antara pihak pemerintah, swasta atau industri pariwisata dan masyarakat setempat yang terkait.
\end{abstract}

Kata Kunci : Masyarakat Lokal, Daya Tarik, Arung Jeram, Papualangi

Available Online at http: //journal.umgo.ac.id/index.php/Tulip

TULIP: Tulisan Ilmiah Pariwisata, Vol. 2, No. 2 Desember 2019, 130-148 


\section{A. PENDAhUluAN}

Setiap daerah wisata mempunyai citra (image) tertentu, yaitu mental maps seseorang terhadap suatu destinasi yang di dalamnya mengandung keyakinan, kesan, dan persepsi. Suatu daerah harus memiliki potensi daya tarik yang besar agar para wisatawan mau menjadikan tempat tersebut sebagai destinasi wisata. Salah satu daerah yang mempunyai kegiatan pariwisata yaitu yang ada di Kabupaten Gorontalo Utara yang digemari saat ini adalah, kegiatan arung jeram di Desa Papualangi Kecamatan Tolinggula. Dengan adanya peran masyarakat sebagai pelaku pendukung kegiatan pariwisata, masyarakat menjadi memiliki peran utama dalam usaha memajukan suatu kawasan daerah wisata, dimana masyarakat bertanggungjawab atas pemeliharaan dan pengelolaan serta manajemen dalam kawasan daerah tersebut. Karena masyarakat juga merupakan salah satu pilar utama dalam pengembangan pariwisata, maka tugas masyarakat adalah membangkitkan kesadaran tentang pentingnya pengembangan pariwisata.

Partisipasi masyarakat dalam pemeliharaan sumber daya alam yang dimiliki merupakan andil yang besar dan berpotensi menjadi objek wisata. Selain itu, dengan mengikutsertakan masyarakat dalam proses dan usaha pengembangan pariwisata sangat penting, sehingga dari masyarakat itu sendiri memiliki rasa tanggung jawab untuk menjaga kelestarian potensi sumber daya alam yang dimiliki.

Masyarakat sebagai komponen utama dalam pembangunan pariwisata berbasis masyarakat mempunyai peranan penting dalam menunjang pembangunan pariwisata yang ditujukan untuk mengembangkan potensi lokal yang bersumber dari alam, sosial budaya ataupun ekonomi masyarakat. Peran serta masyarakat dalam memelihara sumber daya alam dan budaya yang dimiliki merupakan andil yang besar dan berpotensi menjadi daya tarik wisata.

Partisipasi masyarakat sangat menentukan dalam pengembangan desa wisata, agar tidak terlepas dari nilai-nilai budaya masyarakat setempat dan terjadi penurunan kualitas lingkungan, sehingga dalam pengelolaan pariwisata akan dapat mewujudkan masyarakat yang sejahtera seiring dengan kelestarian alam. Prinsip dari penyelengaraan tata kelola kepariwisataan yang baik pada intinya adalah adanya koordinasi antar pemangku kepentingan yang ada serta keterlibatan partisipasi aktif yang sinergis (terpadu dan saling menguatkan) antara pihak pemerintah, swasta atau industri pariwisata, dan masyarakat 
setempat yang terkait. Wujud partisipasi masyarakat terkait yaitu mengawasi dan mengontrol pembangunan kepariwisataan yang ada dengan ikut terlibat dalam menentukan visi, misi dan tujuan pengembangan kepariwisataan, mengidentifkasi sumber daya yang dilindungi, dikembangkan dan dimanfaatkan untuk pengembangan dan pengelolaan daya tarik wisata.

Pengembangan wisata alam dan wisata budaya dalam perspektif kemandirian lokal merupakan perwujudan interkoneksitas dalam tatanan masyarakat yang dilakukan secara mandiri oleh tatanan itu sendiri guna meningkatkan kualitas tatanan dengan tetap memelihara kelestarian alam dan nilainilai budaya lokal, serta obyek wisata alam dan wisata budaya yang ada. Selama ini pengembangan pariwisata daerah ditujukan untuk mengembangkan potensi lokal yang bersumber dari alam, sosial budaya ataupun ekonomi guna memberikan kontribusi bagi pemerintah daerah, sekaligus meningkatkan kesejahteraan masyarakat.

Selama ini kita ketahui bahwa keterlibatan partisipasi masyarakat terhadap daya tarik wisata sangat minim. Hal ini dikarenakan pengetahuan serta bagaimana cara mengelolanya yang belum diketahui oleh masyarakat tersebut. Kita ketahui bahwa keterlibatan masyarakat terhadap daya tarik wisata sangat minim maka perlunya masyarakat setempat dijadikan sebagai peran utama.

Masyarakat lokal harus terlibat secara aktif dalam pengembangan pariwisata. Tingkat keterlibatan masyarakat dalam pariwisata sangat berbeda dan ini tergantung dari jenis potensi, pengalaman, pengetahuan dan keahlian yang dimiliki oleh individu atau masyarakat lokal tersebut. Daya tarik wisata alam arung jeram di Desa Papualangi ini belum memiliki kelompok sadar wisata (POKDARWIS). Yang secara idealnya Pokdarwis sangat penting untuk pembangunan disalah satu daya tarik wisata. Karena secara garis besar menurut buku pedoman Pokdarwis yang dikeluarkan oleh kementrian pariwisata dan ekonomi kreatif adalah kelembagaan ditingkat masyarakat yang anggotanya terdiri dri para pelaku kepariwisataan yang memiliki kepedulian dan tanggungjawab, serta berperan sebagai penggerak dalam mendukung terciptanya iklim kondusif untuk tumbuh dan berkembangnya kepariwisataan.

Berdasarkan latar belakang masalah diatas, maka tim peneliti kami tertarik untuk melakukan penelitian mengenai peran masyarakat lokal dalam pengelolaan daya tarik wisata alam arungjJeram Papualangi Kabupaten Gorontalo Utara. Sehingga diharapkan dapat mengembangkan

Available Online at http: //journal.umgo.ac.id/index.php/Tulip

TULIP: Tulisan Ilmiah Pariwisata, Vol. 2, No. 2 Desember 2019, 130-148 
pariwisata secara mandiri yang berbasiskan kemasyarakatan. Daya tarik wisata alam arung jeram Papualangi dipilih karena daya tarik wisata alam arung jeram Papualangi ini belum memiliki kelompok sadar wisata (POKDARWIS), yang secara idealnya Pokdarwis sangat penting untuk pengembangan disalah satu daya tarik wisata.

\section{B. HASIL DAN PEMBAHASAN \\ Pengelolaan Pariwisata}

Manajemen dari penyelenggaraan pembangunan kepariwisataan yang berlanjutan dan berwawasan lingkungan sehingga terciptanya good tourism governance akan dapat dengan mudah dikenali melalui berbagai cirri penyelenggaraan yang berbasis pada prinsip-prinsip sebagai berikut :

1. Partisipasi Masyarakat Terkait Masyarakat setempat harus mengawasi atau mengontrol pembangunan kepariwisataan yang ada dengan ikut terlibat dalam menentukan visi, 34 misi dan tujuan pembangunan kepariwisataan, mengidentifikasi sumbersumber daya yang akan dilindungi, dikembangkan dan dimanfaatkan untuk pengembangan dan pengelolaan daya tarik wisata. Masyarakat juga harus berpartisipasi dalam mengimplementasikan rencana dan program yang telah disusun sebelumnya.

2. Keterlibatan Segenap Pemangku Kepentingan Para pelaku dan pemangku kepentingan yang harus terlibat secara aktif dan produktif dalam pembangunan kepariwisataan meliputi kelompok dan institusi LSM (Lembaga Swadaya Mayarakat) bidang pariwisata, kelompok sukarelawan, pemerintah daerah, asosiasi industri wisata, Asosiasi bisnis dan pihak-pihal lain yang berpengaruh dan berkepentingan serta yang akan menerima manfaat dari kegiatan kepariwisataan.

3. Kemitraan Kepemilikan Lokal Pembangunan kepariwisataan harus mampu memberikan kesempatan lapangan pekerjaan yang berkualitas untuk masyarakat stempat. Usaha fasilitas penunjang kepariwisataan serta hotel, restoran, cindera mata, transportasi wisata. Seharusnya dapat dikembangkan dan dipelihara bersama masyarakat setempat melalui model kemitraan yang strategis. 
4. Pemanfaatan Sumber Daya Secara Berlanjut Pembangunan kepariwisataan harus dapat menggunakan sumber daya yang dibutuhkan secara berlanjut, yang artinya kegiatan-kegiatannya harus menghindari penggunaan sumber daya yang tidak dapat diperbaharui (irreversible) secara berlebihan. Dalam pelaksanaannya, program kegiatan pembangunan kepariwisataan harus menjamin bahwa sumber daya alam dan buatan dapat dipelihara dan diperbaiki dengan menggunakan kriteria-kriteria dan standar-standar internasional yang sudah baku.

5. Mengakomodasikan Aspirasi Masyarakat Aspirasi dan tujuan masyarakat setempat hendaknya dapat diakomodasikan dalam program kegiatan kepariwisataan, agar kondisi yang harmonis antara: pengunjung/ wisatawan, pelaku usaha dan masyarakat setempat dapat diwujudkan dengan baik. Misalnya kerja sama dalam pengembangan atraksi wisata budaya atau cultural tourism partnership dapat dilakukan mulai dari tahap perencanaan, manajemen, sampai pada pemasaran.

6. Daya Dukung Lingkungan, Daya dukung lingkungan dalam pembangunan kepariwisataan yang harus dipertimbangkan dan dijadikan pertimbangan utama dalam mengembangkan berbagai fasilitas dan kegiatan kepariwisataan meliputi daya dukung fisik, biotik, sosial-ekonomi dan budaya. Pembangunan dan pengembangan harus sesuai dan serasi dengan batas-batas kapasitas lokal dan daya dukung lingkungan yang ada.

7. Monitor dan Evaluasi Program Kegiatan monitor dan evaluasi dalam program pembangunan kepariwisataan yang berlanjut mencakup mulai dari kegiatan penyusunan pedoman, evaluasi dampak kegiatan wisata serta pengembangan indikator-indikator dan batasan-batasan untuk mengukur dampak pariwisata sampai dengan pelaksanaan pemantauan dan evaluasi keseluruhan kegiatan.

8. Akuntabilitas Lingkungan Perencanaan program pembangunan kepariwisataan harus selalu memberi perhatian yang besar pada kesempatan untuk mendapatkan pekerjaan, peningkatan pendapatan dan perbaikan kesehatan masyarakat yang tercermin dengan jelas dalam kebijakan, program dan strategi pembangunan kepariwisataan yang ada. 


\section{TULISAN ILMIAH PARIMUSATA}

9. Pelatihan Pada Masyarakat Terkait Pembangunan kepariwisataan secara berlanjut selalu membutuhkan pelaksanaan program-program pendidikan dan pelatihan untuk membekali pengetahuan dan keterampilan masyarakat dan meningkatkan kemampuan bisnis secara vocational dan profesional.

10. Promosi dan Advokasi Nilai Budaya Kelokalan, Pembangunan kepariwisataan secara berlanjut juga membutuhkan programprogram promosi dan advokasi penggunaan lahan dan kegiatan yang memperkuat karakter lansekap (sense of place) dan identitas budaya masyarakat setempat secara baik. Kegiatankegiatan dan penggunaan lahan tersebut seharusnya bertujuan untuk mewujudkan pengalaman wisata yang berkualitas yang memberikan kepuasan bagi pengunjung atau wisatawan.

Pemberdayaan masyarakat (komunitas setempat) yang berada di destinasi melalui kegiatan usaha kepariwisataan merupakan salah satu model pembangunan yang sedang mendapatkan banyak perhatian dari berbagai kalangan dan akan menjadi agenda penting dalam pembangunan kepariwisataan ke depan.

Menurut Adimihardja (1999) dalam Bambang Sunaryo (2013: 215) mendefinisikan pemberdayaan masyarakat sebagai suatu proses yang tidak saja hanya mengembangkan potensi ekonomi masyarakat yang sedang tidak berdaya, namun 36 demikian juga harus berupaya dapat meningkatkan harkat dan martabat, rasa percaya diri dan harga dirinya serta terpeliharanya tatanan nilai budaya setempat. Pemberdayaan masyarakat dimaknai sebagai suatu upaya untuk menguatkan power (daya) atau empowering dari golongan masyarakat yang powerless (tidak berdaya), biasanya mereka yang sedang tergolong ke dalam masyarakat yang marjinal.

Dalam kegiatan kepariwisataan ada beberapa pihak yang memiliki peran dan terlibat langsung dalam kegiatan kepariwisataan.

Pentingnya pemberdayaan masyarakat dalam pengembangan kepariwisataan menjadi sorotan penting menurut pakar kepariwisataan dunia. Murphy (1988), Larry Dawyer, Peter Forsyth dan Wayne Dwyer (2010) dalam Bambang Sunaryo (2013: 219) pembangunan 
kepariwisataan harus merupakan suatu "kegiatan yang berbasis pada komunitas, dengan faktor utama bahwa sumber daya dan keunikan komunitas lokal baik berupa elemen fisik maupun non fisik (tradisi dan budaya) yang melekat pada komunitas tersebut harus menjadi penggerak utama dalam pariwisata tersebut.

Bambang Sunaryo (2013:218) Untuk mewujudkan pengembangan pariwisata berjalan dengan baik dan dikelola dengan baik maka hal yang paling mendasar dilakukan adalah bagaimana memfasilitasi keterlibatan yang luas dari komunitas lokal dalam proses pengembangan dan memaksimalkan nilai manfaat sosial dan ekonomi dari kegiatan pariwisata untuk masyarakat setempat. Masyarakat lokal memiliki kedudukan yang sama pentingnya sebagai salah satu pemangku kepentingan (stakeholder) dalam pembangunan kepariwisataan, selain pihak pemerintah dan industri swasta.

Bambang Sunaryo (2013: 219) Berdasarkan konsep pemberdayaan masyarakat dalam pembangunan kepariwisataan maka upaya pemberdayaan masyarakat melalui kepariwisataan pada hakikatnya harus diarahkan pada beberapa hal sebagai bertikut:

a. Meningkatnya kapasitas, peran dan inisiatif masyarakat pembangunan kepariwisataan.

b. Meningkatnya posisi dan kualitas keterlibatan/ partisipasi masyarakat.

c. Meningkatnya nilai manfaat positif pembangunan kepariwisataan bagi kesejahteraan ekonomi masyarakat.

d. Meningkatnya kemampuan masyarakat dalam melakukan perjalanan wisata.

Bambang Sunaryo (2013: 138) mengemukakan bahwa dalam pembangunan kepariwisataan yang berorientasi pada pemberdayaan masyarakat menjadi isu strategi pengembangan kepariwisataan saat ini. Dalam khasanah ilmu kepariwisataan, strategi tersebut dikenal dengan istilah community based tourism (CBT) atau pariwisata berbasis masyarakat. Konstruksi pariwisata berbasis masyarakat community based tourism ini pada prinsipnya merupakan salah satu gagasan yang penting dan kritis dalam perkembangan teori pembangunan kepariwisataan konvensional (growth oriented model) yang seringkali mendapatkan 
banyak kritik telah mengabaikan hak dan meminggirkan masyarakat lokal dari kegiatan kepariwisataan di suatu destinasi.

Murphy dalam Bambang Sunaryo (2013: 139) menyebutkan bahwa pada hakekatnya pembangunan kepariwisataan tidak bisa lepas dari sumber daya dan keunikan komunitas lokal, baik berupa elemen fisik maupun non fisik (tradisi dan budaya), yang merupakan unsur penggerak utama kegiatan wisata itu sendiri sehingga semestinya kepariwisataan harus dipandang sebagai "kegiatan yang berbasis pada komunitas". Batasan pengertian pariwisata berbasis masyarakat atau community based tourism sebagai berikut:

a. Wujud tata kelola kepariwisataan yang memberikan kesempatan kepada masyarakat lokal untuk mengontrol dan terlibat aktif dalam manajemen dan pembangunan kepariwisataan yang ada.

b. Wujud tata kelola kepariwisataan yang dapat memberikan kesempatan pada masyarakat yang terlibat langsung dalam usaha-usaha kepariwisataan juga bisa mendapatkan keuntungan dari kepariwisataan yang ada.

c. Bentuk kepariwisataan yang menuntut pemberdayaan secara sistematik dan demokratis serta distribusi keuntungan yang adil kepada masyarakat yang kurang beruntung yang ada di destinasi.

Sedangkan menurut Hudson dan Timothy (1999) dalam Bambang Sunaryo (2013:139) pariwisata berbasis masyarakat atau community based tourism merupakan pemahaman yang berkaitan dengan kepastian manfaat yang diperoleh oleh masyarakat dan adanya upaya perencanaan pendampingan yang membela masyarakat lokal serta kelompok lain yang memiliki ketertarikan atau minat kepada kepariwisataan setempat, dan tata kelola kepariwisataan yang memberi ruang kontrol yang lebih besar untuk mewujudkan kesejahteraan masyarakat setempat.

Menurut Bambang Sunaryo (2013: 140) secara prinsipal, pariwisata berbasis masyarakat atau community based tourism berkaitan erat dengan adanya kepastian partisipasi aktif dari masyarakat setempat dalam pembangunan kepariwisataan yang ada. Partisipasi masyarakat dalam pariwisata terdiri dari atas dua perspektif, yaitu pastisipasi masyarakat dalam proses pengambilan keputusan dan partisipasi yang 


\section{TULISAN ILMIAH PARIMISATA}

berkaitan dengan distribusi keuntungan yang diterima oleh masyarakat dari pembangunan pariwisata. Oleh karena itu pada dasarnya terdapat tiga prinsip pokok dalam strategi perencanaan pembangunan kepariwisatan yang berbasis pada masyarakat atau community based tourism, yaitu :

a. Mengikutsertakan anggota masyarakat dalam pengambilan keputusan

b. Adanya kepastian masyarakat lokal menerima manfaat dari kegiatan kepariwisataan.

c. Pendidikan kepariwisataan bagi masyarakat lokal.

Menurut Rosida dalam karyanya (2017) menyatakan bahwa masyarakat merupakan salah satu potensi yang perlu dipertimbangkan karena masyarakat merupakan subyek dan obyek dari pengembangan suatu kawasan. Tingkat perkembangan dan pertumbuhan masyarakat akan berpengaruh, baik langsung maupun tidak langsung terhadap arah pengembangan suatu daerah atau kawasan. Masyarakat lokal adalah kelompok masyarakat yang menjalankan tata kehidupan sehari-hari berdasarkan kebiasaan yang sudah diterima sebagai nilai-nilai yang berlaku.

Masyarakat lokal memainkan peranan yang cukup penting dalam pengembangan pariwisata sebagai subjek pembangunan daerah. Oleh karena itu, globalisasi menuntut masyarakat di daerah tujuan wisata untuk mengembangkan keterampilan yang dimiliki tanpa meninggalkan nilai-nilai kultural yang sudah ada. Keterlibatan masyarakat lokal secara aktif dalam pengelolaan wisata pada umumnya berupa penyediaan layanan jasa, misalnya menjadi tour guide bagi para wisatawan

\section{Daya Tarik Wisata}

Setiap Daya tarik wisata diartikan juga sebagai objek wisata namun sesuai peraturan pemerintah Indonesia tahun 2009 kata objek wisata sudah tidak relevan untuk menyebutkan suatu daerah tujuan wisatawan. Pengertian obyek dan daya tarik wisata menurut Marpaung (2002:78) adalah suatu bentukan dari aktifitas dan fasilitas yang berhubungan, yang dapat menarik minat wisatawan atau pengunjung untuk datang ke suatu daerah atau tempat tertentu. 


\section{TULISAN ILMIAH PARIVISATA}

Daya tarik merupakan faktor utama yang menarik wisatawan mengadakan perjalanan mengunjungi suatu tempat, baik suatu tempat primer yang menjadi tujuan utamanya, atau tujuan sekunder yang dikunjungi dalam suatu perjalanaan primer karena keinginannya untuk menyaksikan, merasakan, dan menikmati daya tarik tujuan tersebut. Sedangkan daya tarik sendiri dapat diklasifikasikan ke dalam daya tarik lokasi yang merupakan daya tarik permanen

Suatu daerah untuk menjadi daerah tujuan wisata (DTW) yang baik, harus mengembangkan tiga hal agar daerah tersebut menarik untuk dikunjungi, yakni:

1. Adanya sesuatu yang dapat dilihat (something to see), maksudnya adanya sesuatu yang menarik untuk dilihat, dalam hal ini obyek wisata yang berbeda dengan tempat-tempat lain (mempunyai keunikan tersendiri).

2. Adanya sesuatu yang dapat dibeli (something to buy), yaitu terdapat sesuatu yang menarik dan menjadi ciri khas tempat wisata untuk dibeli, seperti cinderamata untuk dibawa pulang ke daerah masing masing. Suatu objek wisata harus mempunyai fasilitas untuk dapat berbelanja yang menyediakan souvenir maupun kerajinan tangan lainnya..

3. Adanya sesuatu yang dapat dilakukan (something to do), yaitu suatu aktivitas yang dapat dilakukan di tempat itu yang bisa membuat orang yang berkunjung merasa betah di tempat tersebut.

4. What to arrived. Di dalamnya termasuk aksesbilitas, bagaimana kita mengunjungi daya tarik wisata tersebut, kendaraan apa yang akan digunakan dan berapa lama tiba ketempat tujuan wisata tersebut.

5. What to stay. Bagaimana wisatawan akan tingggal untuk sementara selama dia berlibut. Diperlukan penginapanpenginapan baik hotel berbintang atau hotel non berbintang dan sebagainya.

Selain itu pada umunya daya tarik wisata suatu objek wisata berdasarkan atas :

Available Online at http: //journal.umgo.ac.id/index.php/Tulip 


\section{TULISAN ILMIAH PARIMISATA}

1. Adanya sumber daya yang dapat menimbulkan rasa senang, indah, nyaman dan bersih.

2. Adanya aksesibilitas yang tinggi untuk dapat mengunjunginya.

3. Adanya ciri khusus atau spesifikasi yang bersifat langka .

4. Adanya sarana dan prasarana penunjang untuk melayani para wisatawan yang hadir.

5. Punya daya tarik tinggi karena memiliki nilai khusus dalam bentuk atraksi kesenian, upacaraupacara adat, nilai luhur yang terkandung dalam suatu objek buah karya manusia pada masa lampau.

Syarat-syarat Untuk Daerah Daya Tarik Wisata Pembangunan suatu objek wisata harus dirancang dengan bersumber pada potensi daya tarik yang dimiliki objek tersebut dengan mengacu pada ceritera keberhasilan pengembangan yang meliputi berbagai kelayakan, yaitu diantaranya adalah:

1. Kelayakan Finansial. Studi kelayakan ini menyangkut perhitungan secara komersial dan pembangunan objek wisata tersebut. Perkiraan untung-rugi sudah harus diperkirakan dari awal. Berapa tenggang waktu yang dibutuhkan untuk kembali modal pun sudah harus diramalkan.

2. Kelayakan Sosial Ekonomi Regional. Studi kelayakan ini dilakukan untuk melihat apakah investasi yang ditanamkan untuk membangun suatu objek wisata juga akan memiliki dampak sosial ekonomi secara regional; dapat menciptakan lapangan kerja berusaha, dapat meningkatkan penerimaan devisa, dapat meningkatkan penerimaan pada sektor yang lain seperti pajak, perindustrian, perdagangan, pertanian, dan lain sebagainya. Dalam kaitannya dengan hal ini pertimbangan tidak semata-mata komersial saja tetapi juga memperhatikan dampaknya secara lebih luas.

3. Layak Teknis Pembangunan, objek wisata harus dapat dipertanggungjawabkan secara teknis dengan melihat daya dukung yang ada. Tidaklah perlu memaksakan diri untuk membangun suatu objek wisata apabila daya dukung objek wisata tersebut rendah. Daya tarik suatu objek wisata tersebut membahayakan keselamatan para wisatawan. 


\section{TULISAN ILMIAH PARIMISATA}

4. Layak Lingkungan. Analisis dampak lingkungan dapat dipergunakan sebagai acuan kegiatan pembangunan suatu objek wisata. Pembangunan objek wisata yang mengakibatkan rusaknya lingkungan harus dihentikan pembangunannya. Pebangunan objek wisata bukanlah untuk merusak lingkungan, tetapi sekedar memanfaatkan sumber daya alam untuk kebaikan manusia dan untuk meningkatkan kualitas hidup manusia sehingga terciptanya keseimbangan, keselarasan, dan keserasian hubungan antara manusia dengan lingkungan alam dan manusia dengan Tuhannya.

\section{Wisata Alam Arung Jeram}

International Rafting Federation (IRF) pada tahun 2002, mengartikan bahwa kegiatan arung jeram sebagai aktifitas yang dilakukan oleh orang yang memiliki kemampuan dan kemauan untuk mengandalkan kemampuan fisiknya dalam mendayung mengarungi sungai dengan menggunakan perahu berbahan keras maupun lunak, yang dilakukan secara terorganisir maupun tidak yang secara kompetitif dan umum yang diterima sebagai suatu kegiatan petualangan.

Petualangan arung jeram pada beberapa dekade ini baik yang bersifat aktif atau game maupun pasif atau leisure banyak digemari oleh kalangan muda di seluruh dunia, bukan hanya di negara maju saja namun kegiatan petualangan ini juga digemari di Indonesia. Terbentuknya Federasi Arung Jeram Indonesia (FAJI) pada tahun 1996 menjadi salah satu titik tolak naiknya perkembangan arung jeram di Indonesia. Hal ini di awali dengan banyaknya bermunculan perkumpulan atau klub arung jeram yang menjadi ladang utama bagi perusahan arung jeram yang tergabung dalam Gabungan Pengusaha Wisata Bahari Indonesia (Gahawisri) sebagai operator rafting.

Wahana dalam kegiatan arung jeram terdiri dari perahu karet, kayak, kano dan dayung. Tujuan arung jeram bisa dilihat dari sisi olah raga, rekreasi dan ekspedisi. Arung jeram sebagai kegiatan petualangan berkelompok, sangat mengandalkan pada kekompakan tim secara keseluruhan. Kerja sama yang terpadu dan pengertian yang dalam antar awak perahu, dapat dikatakan sebagai faktor utama yang menunjang keberhasilan melewati berbagai hambatan di sungai. Tak dapat dibantah bahwa arung jeram merupakan aktivitas yang penuh resiko (high risk 
activities). Namun demikian, setiap orang mampu melakukannya, asalkan wisatawan dalam kondisi yang prima baik dari segi fisik maupun mental.

Khusus untuk perusahan penyedia jasa kegiatan wisata alam seperti arung jeram harus mampu menyediakan sarana dan prasarana yang memadai dan selalu mengutamakan keselamatan wisatawannya. Produk yang ditawarkan oleh perusahaan arung jeram biasanya berkaitan dengan pelayanan yang dapat dilihat secara langsung atau berwujud (tangible product) seperti: peralatan rafting riverboats (perahu), life jackets (pelampung), dayung, waterproof bag, penampilan karyawan dan pelayanan lainnya yang dapat dilihat. Selain itu ada juga produk yang tidak dapat dilihat (intangible product) seperti: informasi yang disampaikan oleh pemandu (guide Rafting), kenyamanan selama mengarungi aliran sungai dan layanan - layanan yang tidak bisa dilihat karena berhubungan dengan kenyamanan dan kepuasan wisatawan yang memakai produk tersebut. Wisatawan yang datang untuk menikmati aktivitas wisata arung jeram tersebut biasanya termotivasi oleh; pencarian pengalaman baru, tantangan, dan keunikan yang ditawarkan melalui aktifitas yang ada tersebut. Keanekaragaman produk yang ditawarkan sudah dikombinasikan dengan beberapa aktifitas seperti; arung jeram dengan pertunjukan binatang (animal show), arung jeram dengan bersepeda diareal persawahan (cycling) dan juga ada paket arung jeram dengan berjalan melintasi area persawahan dan perkebunan masyarakat setempat (Trekking). Hal ini menunjukkan adanya pengembangan bisnis kreatif, tentunya ide-ide kreatif ini muncul tidak terlepas dari masukan atau saran-saran positif dari berbagai pihak diantaranya wisatawan dan para stakeholder. Dengan banyaknya usaha wisata arung jeram di Bali, diharapkan usaha tersebut memiliki kualitas produk dan pelayanan yang baik sehingga para wisatawan yang menikmati fasilitas arung jeram tersebut dapat merasakan kepuasan, kenyamanan dan keamanan yang selalu diharapkan oleh para wisatawan 


\section{TULISAN ILMIAH PARIWISATA}

\section{PEMBAHASAN}

\section{Peran Masyarakat Dalam Pengembangan Daya Tarik Wisata Alam Arum Jeram Papualangi}

Peran masyarakat lokal dalam pengembangan daya tarik wisata disuatu daerah sangatlah penting, karena merekalah yang menyediakan sebagian besar atraksi wisata sekaligus menentukan kualitas produk wisata. Oleh sebab itu perubahan-perubahan yang terjadi di suatu daerah wisata akan bersentuhan langsung dengan kebutuhan mereka. Dilain pihak, peran masyarakat lokal dapat terwujud karena manfaatnya dapat secara langsung dirasakan melalui terbukannya kesempatan kerja bagi masyarakat lokal yang mampu meningkatkan pendapatan mereka dan kesejahreaan hidup mereka.

Peran aktif masyarakat lokal yang bekerja secara perseorangan maupun secara bersama-sama yang secara sadar ikut membantu program pemerintah dengan inisiatif dan kreasi mau melibatkan diri dalam kegiatan pengembangan daya tarik wisata. Negara harus mengenal dan mendorong sepenuhnya identitas, budaya dan keinginan mereka serta menguatkan partisipasi mereka secara efektif dalam mencapai pembangunan berkelanjutan.

Peran masyarakat dalam pelaksanaan kepariwisataan sangatlah besar dan perlu diseimbangkan dengan peran pemerintah maupun swasta. Tetapi kenyataannya yang terjadi peran masyarakat masih sangat kecil bila dibandingkan dengan kedua stakeholder lainnya. Penyebabnya adalah tidak adanya atau lemahnya akses yang mereka miliki kepada sumberdaya (resource) pariwisata yang ada dan rendahnya pelibatan mereka dalam proses pengambilan keputusan. 


\section{TULISAN ILMIAH PARIMISATA}

UU No.9 Tahun 1990 tentang kepariwisataan menyatakan bahwa masyarakat memiliki kesempatan yang sama dan seluas-luasnya untuk berperan serta dalam penyelenggaraan kepariwisataan. Peran masyarakat lokal dalam memelihara sumber daya alam dan budaya yang dimiliki merupakan andil yang besar dan berpotensi menjadi daya tarik wisata.

\section{Peran Masyarakat Lokal Dalam Meningkatkan Kunjungan Wisatawan Di Daya Tarik Wisata Alam Arum Jeram Papualangi}

Berkembangnya pariwisata arum jeram papualangi akan membawa perubahan pada daerah tersebut. Perubahan yang di maksud dapat bernilai positif jika pengembangan pariwisata dilaksanakan dengan mengikuti prosedur yang benar, yakni melalui perencanaan yang cermat dan matang supaya sesuai dengan kondisi setempat. Namun demikian, jika pelaksanaanya tidak dilakukan dengan baik maka justru akan membawa kerugian di daerah wisata arum jeram papualangi.

\section{Hambatan Yang Di Hadapi Masyarakat Lokal Dalam Meningkatkan Kunjungan Di Daya Tarik Wisata Alam Arum Jeram Papualangi}

Dalam proses pengembangan dalam segala hal pasti terbatas, banyak kendala-kendala yang di hadapi dan minimnya SDM yang terampil. Baragam hambatan dan tantangan di hadapi masyarakat lokal dalam pengembangan wisata arum jeram papualangi.

1. Kurangnya pelayanan dasar untuk melayani wisatawan

Minimnya pengetahuan tentang bagaimana cara melayani wisatawan yang berkunjung

2. Jauhnya jarak antar daya tarik wisata wisata Jarak anatara daya tarik wisata arum jeram papualangi cukup jauh sehingga memakan waktu yang cukup lama 


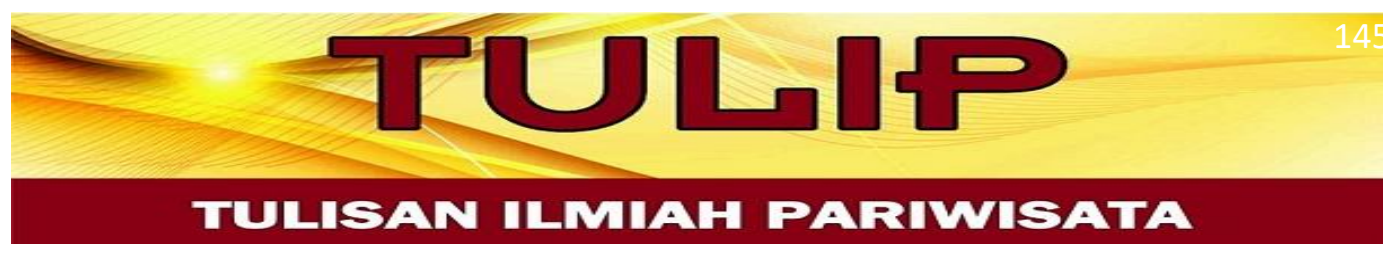

3. Kurangnya pemandu wisata berbahasa asing

Kurangnya sumber daya manusia yang memiliki keahlian atau keterampilan dalam berbahasa asing

4. Terbatasnya tenaga kerja terampil

Kurangnya keterampilan masyarakat lokal yang terampil untuk membuat souvenir di daerah wisata arum jeram papualangi

5. Promosi dari pengelolaan yang masih sangat minim dan terbatas

6. Minimnya kerjasama dengan berbagai pihak, contoh travel agent

7. Minimnya kendaraan menuju lokasi wisata arum jeram papualangi

8. Kurangnya sadar wisata masyarakat lainya

9. Kurangnya kreativitas masyarakat lokal untuk membuat atraksi wisata maupun kegiatan outbond

\section{Pengaruh Masyarakat Lokal Dalam Peningkatan Kunjungan Di Destinasi Wisata Arum Jeram Papualangi}

Pengembangan destinasi wisata yang bertujuan untuk meningkatkan kesejahteraan masyarakat lokal tidak lepas dari keterlibatan masyrakat lokal dalam pengembangan wisata arum jeram papualangi. Pengelolaan destinasi wisata yang dilakukan masyarakat lokal lebih di kenal dengan community based tourism (CBT) atau pariwisata berbasis masyarakat. Pembangunan wisata arum jeram papualngi dengan mengoptimalkan sumber daya manusia masyarakat setempat memerlukan pengorganisasian yang bergerak dalam berbagai bidang yang terkait dengan kegiatan pariwisata.

Masyarakat lokal sebagai stakeholder sangat membantu dalam peningkatan kunjungan wisatawan arum jeram papualangi, terlihat dari strategi yang di terapkan masyarakat lokal untuk meningkatkan kunjungan wisatawan domestik maupun wisatawan mancanegara.

Available Online at http: //journal.umgo.ac.id/index.php/Tulip 


\section{TULISAN ILMIAH PARIMISATA}

Keterlibatan masyarakat lokal sebagai kunci utama dari prinsip pengembangan pariwisata, dapat diimplementasikan dalam tiga tahap,yaitu perencanaan, pelaksanaan serta dalam pemanfaatan keuntungan baik secara ekonomi maupun social budaya.

1. Tahap perencanaan, pada tahap ini memposisikan masyarakat sebagai subjek pengembangan yang berperan aktif dalam proses perencanaan. Tahap perencanaan di lakukan dengan memposisikan masyarakat sebagai subjek dan meliputi tahap identifikasi masalah atau persoalan, identifikasi potensi pengembangan, pengembangan alternative rencana dan fasilitas.

2. Tahap implementasi, bentuk keterlibatan masyarakat terutama terkait dengan partisipasi masyarakat dalam pelaksanaan program pengembangan/pembangunan, pengelolaan objek atau usaha yang terkait dengan kegiatan.

3. Aspek dampak manfaat, bentuk partisipasi masyarakat terwujud dalam peran dan posisi masyarakat memperoleh nilai manfaat signifikan, baik secara ekonomi maupun social budaya, yang berdampak pada peningkatan kesejahteraan ekonomi masyarakat lokal. 


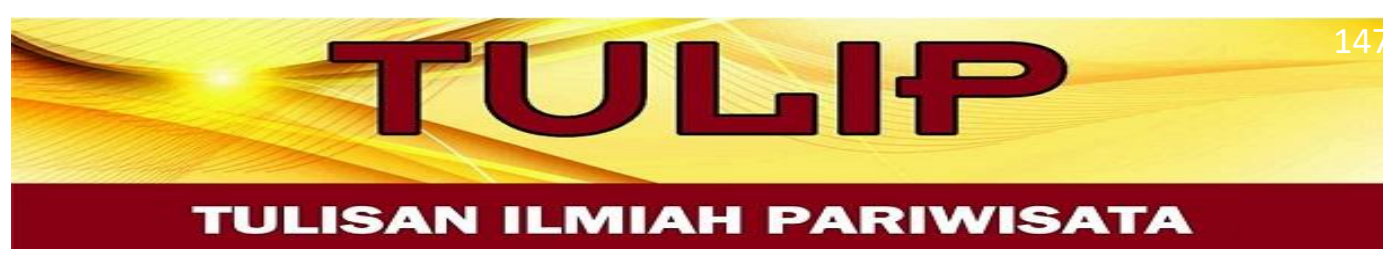

\section{KESIMPULAN}

Daya tarik wisata arum jeram papualangi memiliki potensi yang sangat besar jika dikembangkan dengan baik. Dalam mengembangkan daya tarik wisata arum jeram papualngi di perlukan strategi-strategi guna menyelesaikan semua hambatan-hambatan yang menjadi penghambat dalam pengembangan daya tarik wisata arum jeram papualangi.

Berkembangnya suatu daya tarik dapat dilihat dengan jumlah kunjungan wisatawan yang datang baik lokal maupun mancanegara. Dari strategi-strategi yang di terapkan tentu sangat membantu terlihat dari peningkatan jumlah kunjungan wisatawan lokal maupun mancanegara ke daya tarik wisata arum jeram papualangi.

Adapun kesimpulan yang penulis rangkum adalah :

1. Masyarakat lokal dalam peningkatan kunjungan wisatawan telah melakukan strategi yang sangat membantu, adapun strategi tersebut adalah pemeliharaan lingkungan, meletakkan tempat pembuangan sampah di titik tertentu, perbaikan fasilitas, pembuatan papan petunjuk dan informasi, pembuatan toilet umum, dan pembuatan lahan parker.

2. Masyarakat lokal masih memiliki hambatan yang harus di selesaikan secepatnya, dimana hambatan tersebut seperti kurangnya sadar wisata masyarakat lokal, kurangnya pemandu wisata, kurangnya kerja sama dengan travel, kurangnya kreativitas masyarakat untuk membuat souvenir. 


\section{TULISAN ILMIAH PARIMISATA}

\section{DAFTAR PUSTAKA}

Anggiar, R.F. Djamhur, H. Luchman, H. 2016. Peran serta masyarakat desa dalam inisiasi pengembangan wisata alam desa wringinanom poncokusumo kabupaten malang:32-33.

Anggraeyny, A.M.Y. 2019. Peran kelompok sadar wisata (pokdarwis) sonokeling dalam pengembangan wisata basecamp gunung tanggamis. Skripsi. Fakultas IImu Sosial Dan IImu Politik Unuversitas Lampung.

Cholisoh, S. 2018. Pengembangan wisata alam arung jeram di sungai elo oleh komunitas operator arung jeram kabupaten magelang. Skripsi. Fakultas Dakwah Dan Komunikasi Universitas Islam Negeri Sunan Kalijaga Yogyakarta.

Dewiyuhana. 2007. Arung jeram kasembon:10-11

G Roy, L.I. 2011. Peran serta masyarakat dalam pengelolaan kawasan wisata bukit gundaling kabupaten karo. Tugas akhir. Fakultas Teknik Universitas Diponegoro Semarang.

James, J.S. 2002. Ekonomi pariwisata sejarah dan prospeknya, Yogyakarta:karnisius.

Setiawan, L.R. 2016. Pengembangan sumber daya manusia dibidang pariwisata : perspektif potensi wisata daerah berkembang:24

Siradj, Z.A. 2009. Peran masyarakat dalam pengembangan pariwisata, Jakarta.

Suryawan, A. 2016. Peran kelompok sadar wisata (pokdarwis) sedang arum dalam pengembangan potensi pariwisata. Skripsi. Fakultas IImu Pendidikan Universitas Negeri Yogyakarta.

Wardhani, A.A. 2016. Peran pokdarwis dalam pengembangan desa wisata:2-3. 